\title{
OBITUARIES
}

\section{John Linton Myres}

Sir John Myres was born on 3rd July, 1869, the son of the Rev. W. M. Myres. From Winchester he came as a scholar to New College, Oxford, already enjoying a reputation for dull erudition; but, unlike that of most scholars, this dullness decreased as the erudition increased, and the papers which he read to undergraduate societies became models of lively, even provocative, learning. Awarded a Fellowship by examination at Magdalen College in 1892, he travelled extensively in Crete and Asia Minor to undertake excavations in Cyprus and reorganize the Museum, of which he published a catalogue in 1899. His election as a Student and Tutor in Ancient History at Christ Church in 1895 limited these travels to the vacations but did not end them. During this period he produced his History of Rome, which hardly belied his reputation for dullness ; it was said to have been written in a single long vacation to fulfil a bet made with Haverfield. He left Oxford to become Professor of Greek and Lecturer in Ancient Geography at Liverpool in 1907 but returned in 1910 as Wykeham Professor of Ancient History and Fellow of New College. The war, however, soon called him away and he joined the Navy, for which his extensive knowledge of the Greek islands and the Turkish coasts had marked him down ; the story of his exploits there would fill a book. Returning to Oxford, he soon became the outstanding teacher in the School of Literre Humaniores, training many destined to become leaders in archæology. Nothing came amiss to him, from the details of a piece of Hellenic armour to the contents of a barrow in England; his knowledge of East European anthropology and folk-lore and Anatolian geography was equally extensive. The handling of actual objects found in excavations and wide travel gave him a wonderful eye for visual detail which a prodigious memory kept sharp and vivid; this, with a similar ability to visualize what he had read, invested all he said or wrote with colour and brilliance. It illumined for instance, the Catalogue of the Cesnola Collection of Antiquities from Cyprus equally with the Dawn of History, bringing the scene clearly before the reader's eyes. Yet such brilliance, while it stimulated, also raised doubts: was, for example, Aristotle so simple as Myres' Political Ideas of the Greeks painted him? He was no mere scholar but an able organizer and gave much time to 
running the archæological section of the British Association and many learned societies, including the Palestine Exploration Fund. He planned and carried out the building of the new library at New College; though even here the doubter is tempted to ask whether great ingenuity has not occasionally outrun practical sense. In his last years arthritis crippled him, but with unfailing courage he completed the two volumes of Scripta Minoa whjch Sir Arthur Evans had left unfinished. He died on 6th March, 1954, as he would have wished, still working.

\section{G. R. DrIver.}

\section{Dr. Philippus Samuel van Ronkel}

Dr. Philippus Samuel van Ronkel was born at Zutphen on 1st August, 1870, and died at Leiden on 3rd July, 1954.

After passing the final examination of the Leiden gymnasium he studied Samitic and Indonesian languages at Leiden under Professors De Goeje, Kern, and Vreede. In 1895 he got his Ph.D. for a thesis on "De roman van Amir Hamza. Until 1913 when it was abolished, he taught Malay and Muhammadan Law at Batavia in a School for the instruction of administrative officials. Then he was entrusted with an inquiry into the religions current on Sumatra's West Coast.

In 1920 van Ronkel was one of the founders of the Oriental Society of the Netherlands, of which he became President in 1939. In 1920, too, he was elected a member of the Royal Netherlands Academy of Sciences and from 1921 to 1941 he was Professor of Malay at Leiden. His principal works were Catalogues of the Malay (1909) and Arabic (1913) MSS. in the Museum of the Batavian Society, and of the Malay and Minanghaban MSS. in the Leiden University Library, and editions of the fifteenth century Malacca Laws (1919) and of 'adat radja-radja Melajoe (1929). He contributed numerous articles to the Bijdragen Koninklijk Instituut (18961946) and to the Tijdschrift Bataviaasch Genootschap (1899-1914), including two important papers on Tamil words in Malay (vols. 45 and 46). A paper on the study of Malay in seventeenth century England appeared in Feestbundel Bataviaasch Genootschap (pp. 309$315)$.

Best known to the public for his Malay Dictionary (1918) which ran into a fifth edition (1947), and has been superseded only on JRAS. OCTOBER 1954. 